\title{
The influence of Servive Quality and Corporate Image toward Customer Satisfaction at BPJS Ketenagakerjaan KCP Kendal
}

\author{
Dwi Utami, Winarto*, Azizah \\ Applied Business Administration, State Politechnic of Semarang, Indonesia
}

\begin{abstract}
The aims of this research was to determine the influence of Service Quality and Corporate Image on Customers Satisfaction toward BPJS Ketenagakerjaan KCP Kendal. The methods of data collection are interview, questionnaires, and literature review. The questionnaires used is Differential Semantik with 5-point scale and the sample collection method is accidental sampling with 100 of customers at BPJS Ketenagakerjaan KCP Kendal. The analysis technique used in this research are validity test, reliability test, normality test, heteroskedastisity test, multicolinearity test, linearity test, multiple linear regression, $t$ test, $F$ test and coefficient of determination. Based on calculations using SPSS version 23, the result of this research showes that the regression equation was $Y=1,165+0,190 X 1+0,453 X 2$. The result of this study explaines that the variable service quality and corporate image has positive and significant effect on customer satisfaction. The coefficient of determination in this research was 0,741, which means service quality and corporate image affect the variable of customer satisfaction by $74,1 \%$, while the rest are influenced by other variables outside this regression model.
\end{abstract}

Key words: Service Quality, Corporate Image and Customer Satisfication. 


\title{
Pengaruh Kualitas Layanan dan Citra Lembaga terhadap Kepuasan Pelanggan BPJS Ketenagakerjaan KCP Kendal
}

\begin{abstract}
Abstrak
Penelitian ini bertujuan untuk mengetahui pengaruh Kualitas Layanan dan Citra Lembaga terhadap Kepuasan Pelanggan BPJS Ketenagakerjaan KCP Kendal. Metode pengumpulan data yang digunakan adalah wawancara, kuesioner dan studi pustaka. Kuesioner yang digunakan adalah Differential Semantik dengan skala 5 poin dan metode pengumpulan sampel yang digunakan adalah accidental sampling dengan sampel 100 pelanggan BPJS Ketenagakerjaan KCP Kendal. Teknik analisis yang digunakan adalah uji validitas, uji reliabilitas, uji normalitas, uji heteroskedastisitas, uji multikolinearitas, uji linieritas, regresi linier berganda, uji t, uji F, dan koefisien determinasi. Berdasarkan hasil perhitungan menggunakan SPSS versi 23, hasil penelitian ini menunjukkan bahwa persamaan regresi yang diperoleh adalah $Y=\mathbf{1 , 1 6 5}+\mathbf{0 , 1 9 0}$ $\mathbf{X 1}+\mathbf{0 , 4 5 3}$ X2. Hasil ini menunjukkan bahwa variabel Kualitas Layanan (X1) dan Citra Lembaga (X2) berpengaruh positif dan signifikan terhadap Kepuasan Pelanggan (Y). Koefisien determinasi pada penelitian ini 0,741 yang berarti kualitas layanan dan citra lembaga mempengaruhi variabel kepuasan pelanggan sebesar 74,1\%, sedangkan sisanya dipengaruhi oleh variabel lain di luar model regresi ini.
\end{abstract}

Kata kunci: Kualitas Layanan, Citra Lembaga dan Kepuasan Pelanggan 


\section{PENDAHULUAN}

Di era globalisasi ini, setiap perusahaan dihadapkan oleh persaingan dunia usaha yang semakin ketat. Kunci utama perusahaan agar dapat memenangkan persaingan adalah memberikan nilai dan kepuasan kepada konsumen melalui penyampaian produk dan jasa yang berkualitas. Tjiptono dalam (Utari, 2014).

Seiring dengan perkembangan zaman dan perekonomian Indonesia yang semakin maju, maka banyak pula perusahaan yang berdiri diberbagai sektor bidang usaha. Begitu pula dengan perusahaan yang bergerak di bidang asuransi. Jasa asuransi telah menjadi kebutuhan yang dianggap penting bagi sebagian masyarakat, karena dalam menjalankan kehidupan tidak bisa lepas dari berbagai risiko yang meliputi hidup baik yang bisa terjadi pada diri sendiri maupun pada aset-aset yang dimiliki, seringkali menimbulkan dampak finansial atau keuangan. Demikian pula dengan asuransi jasa ketenagakerjaan, menurut UU No.24
Tahun 2011 Pasal 15 Ayat (1): "Pemberi Kerja wajib mendaftarkan dirinya dan pekerjanya sebagai peserta kepada BPJS sesuai dengan program jaminan sosial yang diikuti", sehingga bagi para pekerja di Indonesia jasa ketenagakerjaan merupakan hal yang krusial dan wajib untuk diikuti. Oleh sebab itu pemerintah mendirikan suatu lembaga asuransi sosial untuk melindungi para pekerjanya dengan nama Badan Penyelenggara Jaminan Sosial Ketenagakerjaan atau yang lebih dikenal dengan BPJS Ketenagakerjaan.

BPJS Ketenagakerjaan berupaya untuk memberikan fasilitas yang terbaik dan pelayanan terbaik untuk seluruh pekerja demi mencapai kepuasan pelayanan oleh pekerja. Karena sebagai perusahaan yang bergerak dalam bidang jasa, pelayanan adalah kunci utama untuk mencapai kepuasan seorang pelanggan.

Pada Tabel 1 disajikan keluhan pelanggan di BPJS Ketenagakerjaan KCP Kendal.

Tabel 1

Jumlah Keluhan Pelanggan BPJS Ketenagakerjaan KCP Kendal Januari - Juni 2020

\begin{tabular}{|l|c|c|c|}
\hline \multicolumn{1}{|c|}{ Bulan } & $\begin{array}{c}\text { Jumlah } \\
\text { Keluhan }\end{array}$ & $\begin{array}{c}\text { Kenaikan } \\
\text { Jumlah } \\
\text { Keluhan }\end{array}$ & $\begin{array}{c}\text { Kenaikan } \\
\text { Jumlah } \\
\text { Keluhan (\%) }\end{array}$ \\
\hline Januari & 21 & - & - \\
\hline Februari & 24 & 3 & $14,2 \%$ \\
\hline Maret & 29 & 5 & $20,8 \%$ \\
\hline April & 35 & 6 & $20,6 \%$ \\
\hline Mei & 44 & 9 & $25,7 \%$ \\
\hline Juni & 55 & 11 & $25,0 \%$ \\
\hline
\end{tabular}

Sumber: BPJS Ketenagakerjaan KCP Kendal

Berdasarkan Tabel 1 dapat dijabarkan sebagai berikut:

1. Berdasarkan tabel jumlah keluhan pelanggan selama 6 bulan terakhir terlihat adanya kenaikan secara terus-menerus pada BPJS ketenagakerjaan KCP Kendal.

2. Kenaikan jumlah keluhan pelanggan tidak sama setiap bulannya, tetapi dapat dilihat kenaikan terbanyak mencapai kenaikan sebesar 11 keluhan pelanggan BPJS Ketenagakerjaan KCP Kendal.

3. Jumlah keluhan terbanyak terdapat pada bulan Juni dimana jumlah keluhan mencapai $25,0 \%$ atau sebanyak 55 keluhan. 
Menurut Kotler dalam (F. G. C. Tjiptono, 2016) untuk mengukur kepuasan pelanggan dapat digunakan beberapa cara salah satunya yaitu sistem keluhan dan saran. Selain kualitas layanan, citra lembaga juga memiliki pengaruh dalam hal tersebut (Saktiani, 2015). Seperti yang dikemukakan (Safitri, Rahayu, \& Indrawati, 2016) bahwa dengan terbentuknya citra yang baik dimata pelanggan, hal ini akan meningkatkan kepuasan dan loyalitas pelanggan terhadap perushaan tersebut. Hal ini diperkuat dengan penelitian (Setiawan, \& Sayuti, 2017) bahwa kualitas layanan dan citra perusahaan berpengaruh yang signifikan tehadap kepuasan pelanggan.

Mengingat pentingnya kualitas layanan dan citra lembaga pada BPJS Ketenagakerjaan KCP Kendal, maka akan dilakukan penelitian dengan judul "Pengaruh Kualitas Layanan dan Citra Lembaga terhadap Kepuasan Pelanggan BPJS Ketenagakerjaan KCP Kendal.”

Tujuan Penelitian

1. Mengukur tingkat kepuasan pelanggan, kualitas layanan dan citra lembaga BPJS Ketenagakerjaan KCP Kendal.

2. Menganalisa dan mengetahui apakah kualitas layanan berpengaruh terhadap kepuasan pelanggan BPJS Ketenagakerjaan KCP Kendal.

3. Menganalisa dan mengetahui apakah citra lembaga berpengaruh terhadap kepuasan pelanggan BPJS Ketenagakerjaan KCP Kendal.

4. Menganalisa dan mengetahui apakah kualitas layanan dan citra lembaga berpengaruh terhadap kepuasan pelanggan BPJS Ketenagakerjaan KCP Kendal.

\section{Kualitas Layanan}

Zeithmal (2017) mengatakan: "Pelanggan tidak mempersepsikan kualitas dengan cara unidimensional melainkan menilai kualitas berdasarkan berbagai faktor yang relevan dengan konteks". Yang dimaksud dengan relevan dalam konteks disini adalah pelanggan kan menilai produk/jasa secara langsung atau saat kondisi tertentu baik berguna secara konteks fisik maupun sosio-psikologis."

Baoaronta dalam (Atiyah 2017) adalah: Kualitas layanan adalah kemampuan suatu organisasi untuk memberikan layanan kepada pelanggan secara akurat dan benar serta dapat diandalkan bagi pelanggan.

Dapat disimpulkan bahwa kualitas layanan adalah upaya memenuhi kebutuhan dan keinginan konsumen serta ketepatan penyampaian layanan dengan harapan konsumen.

\section{Dimensi Kualitas Layanan}

Menurut Parasuraman dalam (F.

Tjiptono, 2009) kualitas jasa/pelayanan

dipengaruhi 5 dimensi mutu pelayanan, yaitu:

1. Tangible (Bukti Fisik)

2. Reliability (Kehandalan)

3. Responsivness (Daya Tanggap)

4. Assurance (Jaminan)

5. Empathy (Empati)

\section{Citra Lembaga}

Nguyen dan Leblanc dalam (Setiawan et al., 2017) mendefinisikan citra lembaga:

Citra lembaga sebagai sesuatu yang berhubungan dengan atribut fisik dan perilaku lembaga seperti nama lembaga, arsitektur, produk dan layanan, kesan kualitas dikomunikasikan oleh konsumen yang telah menggunakan produk dan layanan lembaga. Sedangkan menurut Alma (2013) menyatakan bahwa citra didefinisikan sebagai kesan yang diperoleh sesuai dengan pengetahuan dan pengalaman seseorang tentang suatu lembaga BPJS Ketenagakerjaan KCP Kendal.

\section{Indikator Citra Lembaga}

Menurut Kotler dan Keller dalam (Lesmana, 2017) informasi yang lengkap mengenai citra lembaga meliputi empat elemen sebagai berikut:

1. Kepribadian

2. Reputasi

3. Nilai

4. Identitas Lembaga 


\section{Kepuasan Pelanggan}

Kepuasan pelanggan (customer satisfaction) adalah perasaan senang atau kecewa seseorang yang timbul karena membandingkan kinerja yang dipersepsikan produk (atau hasil) terhadap ekspektasi mereka. Jika kinerja gagal memenuhi ekspektasi, pelanggan akan tidak puas. Jika kinerja sesuai dengan ekspektasi, pelanggan akan puas. Jika kinerja melebihi ekspektasi maka pelanggan akan sangat puas (Kotler, 2018).

Sedangkan menurut Yazid dalam (Suryati, 2019), kepuasan pelanggan adalah ketiadaan perbedaan antara harapan yang dimiliki dan unjuk kerja yang senyatanya diterima. Apabila harapan tinggi, sementara unjuk kerja biasa-biasa saja, kepuasan tidak akan tercapai (sangat memungkinkan konsumen akan kecewa).

\section{Indikator Kepuasan Pelanggan}

1. Perasaan puas

2. Selalu membeli produk

3. Akan Merekomendasikan Kepada Orang Lain

\section{METODE PENELITIAN \\ Populasi dan Sample}

Populasi dalam penelitian ini adalah pelanggan yang telah menerima pelayanan pada BPJS Ketenagakejaan KCP Kendal selama bulan Januari - Desember 2019, dengan jumlah 11.439 pelanggan BPJS Ketenagakerjaan KCP Kendal. Teknik sampel yang digunakan yaitu accidental sampling, dan jumlah sampel yang digunakan berjumlah 100 responden yang dihitung menggunakan rumus slovin.

\section{Kerangka Pemikiran Teoritis}

Kerangka teoritis dalam penelitian ini disajikan pada Gambar 1.

\section{Gambar 1. Kerangka Pemikiran Teoritis}

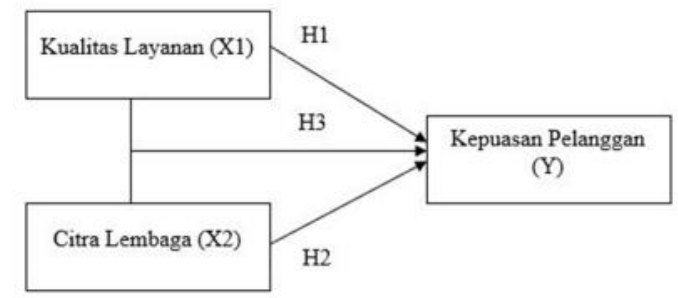

Pada penelitian ini, analisis regresi linier berganda digunakan untuk mengukur kekuatan dan menunjukkan arah pengaruh Kualitas Layanan dan Citra Lembaga terhadap Kepuasan Pelanggan. Persamaan dirumuskan sebagai berikut:

$$
=\quad+{ }_{1 \cdot 1}+2 \cdot 2+
$$

Keterangan:

$\mathrm{Y}=$ Kepuasan Pelanggan

$\mathrm{a}=$ Konstanta

$b_{1}=$ Koefisien regresi untuk $X_{1}$ Kualitas Layanan $b_{2}=$ Koefisien regresi untuk $X_{2}$ Citra Lembaga

$\mathrm{X}_{1}=$ Kualitas Layanan

$\mathrm{X}_{2}=$ Citra Lembaga

$\mathrm{e}=$ Error (nilai residu)

\section{HASIL DAN PEMBAHASAN}

Analisis regresi digunakan untuk menguji kebenaran hipotesis yang diajukan dalam penelitian ini (Sujarweni, 2015). Pada regresi berganda terdapat satu variable terikat dan lebih dari variabel bebas. Dalam penelitian ini yang menjadi variabel terikat adalah kepuasan pelanggan pada BPJS 
Ketenagakerjaan KCP Kendal, sedangkan variabel bebas adalah kualitas layanan dan citra lembaga. Hasil uji regresi linier berganda dapat dilihat pada Tabel 2 .

Tabel 2

Analisis Regresi Linier Berganda

\begin{tabular}{|l|l|l|l|l|l|}
\hline Variable & \multicolumn{2}{|c|}{$\begin{array}{c}\text { Unstandardized } \\
\text { Coefficient }\end{array}$} & $\begin{array}{l}\text { Standardized } \\
\text { Coefficient }\end{array}$ & t & sig \\
\hline & B & Std. Eror & Beta & & \\
\hline Kualitas Layanan & 0.190 & 0.058 & 0.462 & 3.262 & 0.002 \\
\hline Citra Lembaga & 0.453 & 0.067 & 0.293 & 6.779 & 0.000 \\
\hline Constant & $=$ & 1.165 & & & \\
\hline R & $=$ & 0.864 & & & \\
\hline R square & $=$ & 0.747 & & & \\
\hline Adjusted R Square & $=$ & 0.741 & & & \\
\hline F hitung & $=$ & 142.881 & & & \\
\hline Sig. F Arithmetic & $=$ & 0.000 & & & \\
\hline
\end{tabular}

Berdasarkan hasil uji regresi pada Tabel 2, menunjukkan bahwa koefisien regresi untuk variabel Kualitas Layanan (X1) sebesar 0,190, koefisien regresi untuk Citra Lembaga (X2) sebesar 0,453 dan untuk nilai konstantanya adalah 1,165. Berdasarkan keterangan tersebut maka dapat terbentuk persamaan regresi sebagai berikut:

\section{$Y=1,165+0,190 \times 1+0,453 \times 2$}

Persamaan regresi tersebut dapat diartikan sebagai berikut:

a. Variabel Kualitas Layanan (X1)

Kualitas Layanan (X1) berpengaruh positif terhadap Kepuasan Pelanggan (Y) sehingga apabila Kualitas Layanan mengalami peningkatan maka Kepuasan Pelanggan juga akan meningkat.

b. Variabel Citra Lembaga (X2)

Citra Lembaga (X2) berpengaruh positif terhadap Kepuasan Pelanggan (Y) sehingga apabila Citra Lembaga mengalami peningkatan maka Kepuasan Pelanggan juga akan meningkat.

\section{Uji Hipotesis}

1. Kualitas Layanan terhadap Kepuasan Pelanggan.

Berdasarkan hasil pengujian menunjukkan bahwa nilai thitung 3,262 > tabel 1,98447, maka dapat disimpulkan bahwa terdapat pengaruh yang signifikan secara parsial variabel kualitas layanan terhadap kepuasan pelanggan pada BPJS Ketenagakerjaan KCP Kendal. Ha 1 diterima Ditenerimanya Hal maka dapat disimpulkan bahwa variabel kualitas layanan memberikan pengaruh yang signifikan terhadap kepuasan pelanggan, artinya semakin tinggi kualitas layanan maka akan semakin besar kepuasan pelanggan BPJS Ketenagakerjaan KCP Kendal.

2. Citra Lembaga terhadap Kepuasan Pelanggan

Berdasarkan hasil pengujian menunjukkan bahwa nilai $\mathrm{t}$ hitung 6,779 >t tabel 1,98447, maka dapat disimpulkan bahwa terdapat pengaruh yang signifikan secara parsial variabel citra lembaga terhadap kepuasan pelanggan pada BPJS Ketenagakerjaan KCP Kendal. $\mathbf{H a}_{2}$ diterima.

Ditenerimanya Ha2 maka dapat disimpulkan bahwa variabel citra lembaga memberikan pengaruh yang signifikan 
terhadap kepuasan pelanggan, artinya semakin tinggi citra lembaga maka akan semakin besar kepuasan pelanggan BPJS Ketenagakerjaan KCP Kendal.

3. Pengaruh Kualitas Layanan (X1) dan Citra Lembaga (X2) terhadap Kepuasan Pelanggan (Y)

Berdasarkan hasil pengujian menunjukkan bahwa nilai $\mathrm{F}$ hitung sebesar 142,881 > F tabel sebesar 3,09 dengan besar signifikansi 0,000 yang menunjukan bahwa signifikansi kurang dari 0,025, maka dapat disimpulkan bahwa terdapat pengaruh yang signifikan secara simultan variabel kualitas layanan, dan citra lembaga terhadap kepuasan pelanggan BPJS Ketenagakerjaan KCP Kendal. $\mathrm{Ha}_{3}$ diterima.

Diterimanya Ha3 dapat disimpulkan bahwa secara simultan dapat dibuktikan bahwa secara bersama-sama semua variabel kualitas layanan dan citra lembaga dapat mempengaruhi kepuasan pelanggan BPJS Ketenagekerjaan KCP Kendal.

4. Berdasarkan perhitungan analisis regresi linier berganda dapat diketahui bahwa citra lembaga merupakan variabel yang paling dominan berpengaruh terhadap kepuasan pelanggan dengan koefisien regresi sebesar 0,453 melalui indikator kepribadian, reputasi, nilai, dan identitas lembaga.

\section{KESIMPULAN}

Berdasarkan hasil analisis dalam penelitian Skripsi ini, dapat disimpulkan bahwa semua variabel Kualitas Layanan (X1) dan Citra Lembaga (X2) berpengaruh signifikan positif terhadap Kepuasan Pelanggan adapun penjelasannya sebagai berikut:

1. Berdasarkan pengukuran variabel kualitas layanan dan kepuasan pelanggan dapat disimpulkan bahwa:

a. Kualitas layanan (X1)

Variabel kualitas layanan (X1) terdiri dari 5 indikator yaitu bukti fisik (tangible), kehandalan (reliability), daya tanggap (responseveness), jaminan (assurance), dan empati (emphaty). Berdasarkan tanggapan responden mengenai variable kualitas layanan (X1) yang diberikan BPJS Ketenagakerjaan KCP Kendal yaitu sebesar 4,07. Sehingga responden berpendapat secara keseluruhan bahwa kualitas layanan yang telah diberikan BPJS Ketenagakerjaan KCP Kendal tergolong dalam kategori baik.

b. Citra Lembaga (X2)

Variabel Citra Lembaga (X2) terdiri dari empat (4) indikator yaitu kepribadian, reputasi, nilai dan indentitas lembaga. Berdasarkan tanggapan responden mengenai variabel Citra Lembaga (X2) yang dimiliki BPJS Ketenagakerjaan KCP Kendal yaitu sebesar 4,15. Sehingga responden berpendapat secara keseluruhan bahwa citra lembaga BPJS Ketenagakerjaan KCP Kendal tergolong dalam kategori baik.

c. Kepuasan Pelanggan (Y)

Variabel Kepuasan Pelanggan (Y) terdiri dari tiga (3) indikator yaitu terus menggunakan jasa, perasaan puas dan akan merekomendasikan kepada orang lain. Berdasarkan tanggapan responden mengenai variabel kepuasan pelanggan (Y) atas pelayanan dan citra Lembaga yaitu sebesar 4,18. Sehingga responden berpendapat secara keseluruhan bahwa kepuasan pelanggan BPJS Ketenagakerjaan KCP Kendal tergolong dalam kategori baik.

2. Berdasarkan hasil perhitungan analisis regresi linier berganda dihasilkan persamaan regresi yaitu:

$\mathrm{Y}=1,165+0,190 \mathrm{X} 1+0,453 \mathrm{X} 2$.

3. Berdasarkan hasil uji $\mathrm{F}$ Kualitas Layanan (X1) dan Citra Lembaga (X2) berpengaruh signifikan terhadap Kepuasan Pelanggan. Hal tersebut ditunjukkan dengan thitung lebih besar dari ttabel $(142,881>3,09)$ dan 
nilai signifikansi adalah sig $=0,000<$ 0,025. Dengan demikian Ha diterima, maka dapat dinyatakan hipotesis yang menyatakan Kualitas Layanan (X1) dan Citra Lembaga (X2) berpengaruh terhadap Kepuasan Pelanggan (Y) BPJS Ketenagakerjaan KCP Kendal diterima.

4. Hasil koefisien determinasi (Adjusted $R$ Square) menunjukkan bahwa Kualitas Layanan (X1) dan Citra Lembaga (X2) memberikan sumbangan sebesar $74,1 \%$ terhadap kepuasan pelanggan BPJS Ketenagakerjaan. Hasil tersebut menunjukkan bahwa kualitas layanan dan citra lembaga memiliki sumbangan yang besar terhadap kepuasan pelanggan.

\section{Saran}

Berdasarkan hasil penelitian, beberapa saran yang dapat disampaikan adalah sebagai berikut:

1. Berdasarkan hasil analisis deskriptif pada penelitian ini, kepuasan pelanggan sudah baik namun masih perlu ditingkatkan lagi agar pelanggan tetap loyal untuk menggunakan jasa dari BPJS Ketenagakerjaan, mencegah pelanggan beralih pada perusahaan lain, mencegah penilaian negatif terhadap BPJS Ketenagakerjaan dan menarik pelanggan baru.

2. Berdasarkan analisis deskripsi responden atas item-item pertanyaan yang diajukan terdapat item yang perlu ditingkatkan karena memiliki nilai skor dibawah ratarata skor kualitas layanan. BPJS Ketenagakerjaan KCP Kendal perlu meningkatkan waktu layanan yang diberikan kepada pelanggan dan kecepatan pelayanan yang diberikan dengan cara mempercepat waktu layanan.

3. Berdasarkan analisis deskripsi responden atas item-item pertanyaan yang diajukan terdapat item yang perlu ditingkatkan karena memiliki nilai skor dibawah ratarata skor citra lembaga. Citra lembaga perlu ditingkatkan dengan cara memperbaiki fasilitas-fasilitas yang disediakan oleh BPJS Ketenagakerjaan KCP Kendal seperti ruang tunggu yang nyaman, memperluas area parkir, memperhatikan kebesihan toilet dan kebersihan lingkungan kantor.

\section{DAFTAR PUSTAKA}

Alma, B. (2013). Manajeman Pemasaran dan Pemasaran Jasa. Bandung: Alfabeta.

Atiyah, L. (2017). Impact of service quality on customer satisfaction. 11(5), 20-28.

Atmaja, N. (2016). Pengaruh kewajaran harga, citra perusahaan terhadap kepuasan dan loyalitas pengguna jasa penerbangan domestik garuda indonesia di Denpasar. 197-209. Jurnal Ekonomi dan Keuangan.Vol.15. No.3.

Dennisa, E. A., \& Santoso. (2016). Analisis Pengaruh Kualitas Produk, Kualitas Layanan, dan Citra Merek terhadap Loyalitas Pelanggan melalui Kepuasan Pelanggan sebagai Variabel Intervening (Studi pada Klinik Kecantikan Cosmedic Semarang). Diponegoro Journal of Management, Vol. 5 No. 3

Ferdinand, A. (2014). Metode Penelitian Manajemen edisi kelima. Universitas Diponegoro, Semarang: Badan Penerbit.

Ghozali, I. (2016). Aplikasi Analisis Multivariate dengan Program IBM SPSS 23. Semarang: Badan Penerbit Universitas Diponegoro.

Huang, P., Lee, B \& Chen, B. (2019). The influence of service quality on customer satisfaction and loyalty in $B 2 B$ technology service industry. Gothenburg University Journal. Vol. 10. No.2.

Irawan, H. (2008). 10 Prinsip Kepuasan Pelanggan, .Jakarta: Komputindo.

Kasmiruddin, K., \& Rajagukguk, Resti. (2015). Pengaruh Kualitas Pelayanan dan Citra Perusahaan terhadap Kepuasan Pelanggan Industri Jasa Bengkel (Kasus PT. Mewah Kencana Motor Pekanbaru). Riau University Journal. Vol.2. No.2. 
Keller, K. L. (2013). Strategic Brand Management. United Kingdom: Pearson Education Limited.

Kotler, P. K., Kevin Lane. (2018). Manajeman Pemasaran Edisi Ketiga Belas. Jakarta: Penerbit Erlangga.

Lesmana, R. (2017). Pengaruh Citra Perusahaan Terhadap Keputusan Pembelian Konsumen PT. Garuda Indonesia Tbk.(Persero). Jurnal Ilmiah Manajemen Forkamma. Vol. 1. No1.

Lupiyoadi, R., Ikhsan. (2015). Praktikum Metode Riset Bisnis. Jakarta: Salemba Empat.

Mitior, M., \& Susena, K. (2014). Analisis Hubungan Pelayanan dengan Kepuasan Pelanggan pada Bengkel Candera Motor di Kaur Utara Kabupaten Kaur. University Bekalu Journal. Vol.2. No1.

Nugroho, B., \& Subagja. (2018). Pengaruh Kualitas Layanan dan Citra Perusahaan terhadap Kepuasan Nasabah PT. Bank Perkreditan Rakyat Gracia Mandiri Bekasi Timur. Jurnal Manajemen Bisnis Krisnadwipayana. Vol. 6. No.1.

Purba, R., \& Ibrahim, M. (2017). Pengaruh Citra Perusahaan Terhadap Loyalitas Pelanggan (Studi Kasuspt. Bintang Utara Perwakilan Dolok Sanggul). Riau University. Journal of Managemen FISIP. Vol. 4. No.1

Riyanto, S. H., Aglis Andhita. (2020). Metode Riset Penelitian Kuantitatif Penelitian Di Bidang Manajemen, Teknik Pendidikan dan Eksperimen. Yogyakarta: Dee Publish.

Saad, N. M., \& Wahid, A. (2017). The Influence of Store Image and Corporate Image on Customer Satisfaction: A Study in Petrol Station's Convenience Store Patronage in Malaysia. Paper presented at the Management International Conference.

Safitri, E., Rahayu, M., \& Indrawati, N. (2016). Pengaruh Kualitas Pelayanan Dan Citra Perusahaan Terhadap Kepuasan Pelanggan Dan Loyalitas Pelanggan Service Center [Studi Pada
Pelanggan Samsung Service Center Di Kota Malang. Jurnal Ekonomi Bisnis. Vol. 21. No.1.

Saidani, B., \& Arifin, S. (2012). Pengaruh kualitas produk dan kualitas layanan terhadap kepuasan konsumen dan minat beli pada ranch market. 3(1), 1-22. Jurnal Riset Manajemen Sains Indonesia. Vol.3 No.1

Saktiani, G. (2015). Pengaruh Kualitas Layanan dan Citra Perusahaan terhadap Kepuasan Pelanggan dan Word of Mouth. Jurnal Ilmu Sosial dan Ilmu Politik. Vol. 4. No.2.

Setiawan, H., \& Sayuti, A. (2017). Effects of service quality, customer trust and corporate image on customer satisfaction and loyalty: an assessment of travel agencies customer in South Sumatra Indonesia. Journal of Business and Management. Vol. 19. No.3.

Shahabuddin, R. (2019). Manajemen Pemasaran Jasa: Upaya Untuk Meningkatkan Kepuasan Nasabah pada Industri Perbankan. Sulawesi: Pustaka Taman Ilmu.

Sondakh, C. (2015). Kualitas Layanan, Citra Merek Dan Pengaruhnya Terhadap Kepuasan Nasabah Dan Loyalitas Nasabah Tabungan (Studi Pada Nasabah Taplus BNI Cabang Manado). Jurnal Riset Bisnis dan Manajemen. Vol.3.

Sugiyono, P. (2017). Metode Penelitian Bisnis: Pendekatan Kuantitatif, Kualitatif, Kombinasi, dan R\&D. In: Penerbit CV. Alfabeta: Bandung.

Sujarweni, V. W. (2015). Metodologi Penelitian Bisnis \& Ekonomi. Yogyakarta: Pustakabarupress.

Suryati, L. (2019). Manajemen Pemasaran: Suatu Strategi dalam Meningkatkan Loyalitas Pelanggan. Yogyakarta: Deepublish Publisher.

Susilo, H., Haryono, A. T., \& Mukeri, M. (2018). Analisis pengaruh harga, kualitas pelayanan, promosi, dan kepercayaan terhadap kepuasan 
konsumen dengan keputusan berkunjung sebagai variabel intervening di Hotel Amanda Hills Bandungan. Journal of Management. Vol. 4. No.4.

Suwandi, I. M. D. (2007). Citra Perusahaan Seri Manajemen Pemasaran: www.eiman.uni.cc.

Tjiptono, F. (2007). Pemasaran Jasa. Malang: Bayumedia Publishing.

Tjiptono, F. (2009). Service Marketing Esensi \& Aplikasi. Yogyakarta.

Tjiptono, F. G. C. (2016). Service, Quality \& Satisfaction. Yogyakarta: Penerbit Andi.

Utari, W. (2014). Pengaruh Kualitas Layanan, Harga, Varian Obat Dan Fasilitas Terhadap Kepuasan Pelanggan Apotek Yakersuda Bangkalan. Journal Trunojoyo. Vol.8. No.1.
Wardani, T. U. (2017). Pengaruh kualitas pelayanan terhadap kepuasan konsumen pada bisnis jasa transportasi gojek (studi kasus mahasiswa Febi UIN Sumatera Utara). Universitas Islam Negeri Sumatera Utara.

WS, F. S., \& Soliha, E. (2015). Pengaruh Persepsi Harga, Citra Perusahaan, dan Citra Merek terhadap Kepuasan dan Loyalitas Pelanggan pada Apotik" Dela" di Semarang.

Yu, W., \& Ramanathan, R. (2012). Retail service quality, corporate image and behavioural intentions: the mediating effects of customer satisfaction. Journal of Marketing Management. Vol. 22. Issue.5.

Zeithaml, V. A. (2017). Service Marketing Integrating Customers Focus Across the Firm. Mc Graw: Hill Education. 